\title{
Sedimentological characteristics and controlling factors on fluvial styles of the Guantao Formation, Kongdian Oilfield, China
}

\author{
Hai Liu ${ }^{1}, *$ Chengyan Lin ${ }^{1}$, Xianguo Zhang ${ }^{1}$, Hongwei Wang ${ }^{2}$ and Xiaoliang Fu ${ }^{2}$ \\ ${ }^{1}$ School of Geosciences, China University of Petroleum, Qingdao 266 580, China. \\ ${ }^{2}$ China National Petroleum Corporation, Tianjin City, China. \\ *Corresponding author. e-mail: oceliu@163.com
}

MS received 3 March 2017; revised 3 May 2018; accepted 8 May 2018;

published online 1 February 2019

The Kongdian Oilfield is located in eastern China. More than 30 years have passed since the oil field was discovered in 1979. The majority of the oil is produced from reservoirs of the Guantao Formation (Miocene). A detailed description and interpretation of core, well-logging and 3-D seismic stratal slices data was carried out to analyze sedimentological characteristics of the Guantao Formation and two fluvial styles have been identified encompassing braided channel and meandering channel. Seven main facies associations were defined: (i) upward-fining channel, (ii) braided channel with mid-channel bar, (iii) meandering channel with point bar, (iv) levee, (v) floodplain, (vi) minor channel, (vii) swamp. Vertical changes in fluvial styles of the Guantao Formation were recognized by variations in preserved thickness, channels stacking pattern, regional paleoflow directions, and channel/floodplain ratios. The fluvial succession is 50-70 m thick in the lower Guantao Formation, composed of braided channels and high channel/floodplain ratio. The alluvial succession is $60 \mathrm{~m}$ in thickness in the upper Guantao Formation, the dominant fluvial styles change to meandering channels and channel/floodplain ratio reduces. The main factor that may have affected the fluvial style is the base-level changes. With the rise of the base level the fluvial style is believed to have changed from braided channels to meandering channels.

Keywords. Sedimentological characteristics; facies associations; Guantao Formation; fluvial styles; controlling factor; evolutionary model.

\section{Introduction}

The evolution of a river is a complex process and numerous works have been carried out to analyze variations of alluvial styles at several scales (Miall 1977, 1985, 1993; Bridge 1985, 1993, 2000; Ethridge et al. 1998; Jiao and Yan 2005; Allen and Fielding 2007; Smith et al. 2010). Many studies showed that variations of fluvial styles are related to factors such as tectonics, climate, the location of the river (Arche and López-Gómez 1999; Catuneanu and Elango 2001; Marenssi et al. 2005; Huerta et al. 2011). Until now, there are few studies describing the sedimentary characteristics of the Guantao Formation in the Kongdian Oilfield. The existing literature based on the analysis of core, well log and seismic data show that mainly braided channels deposits are developed in the 


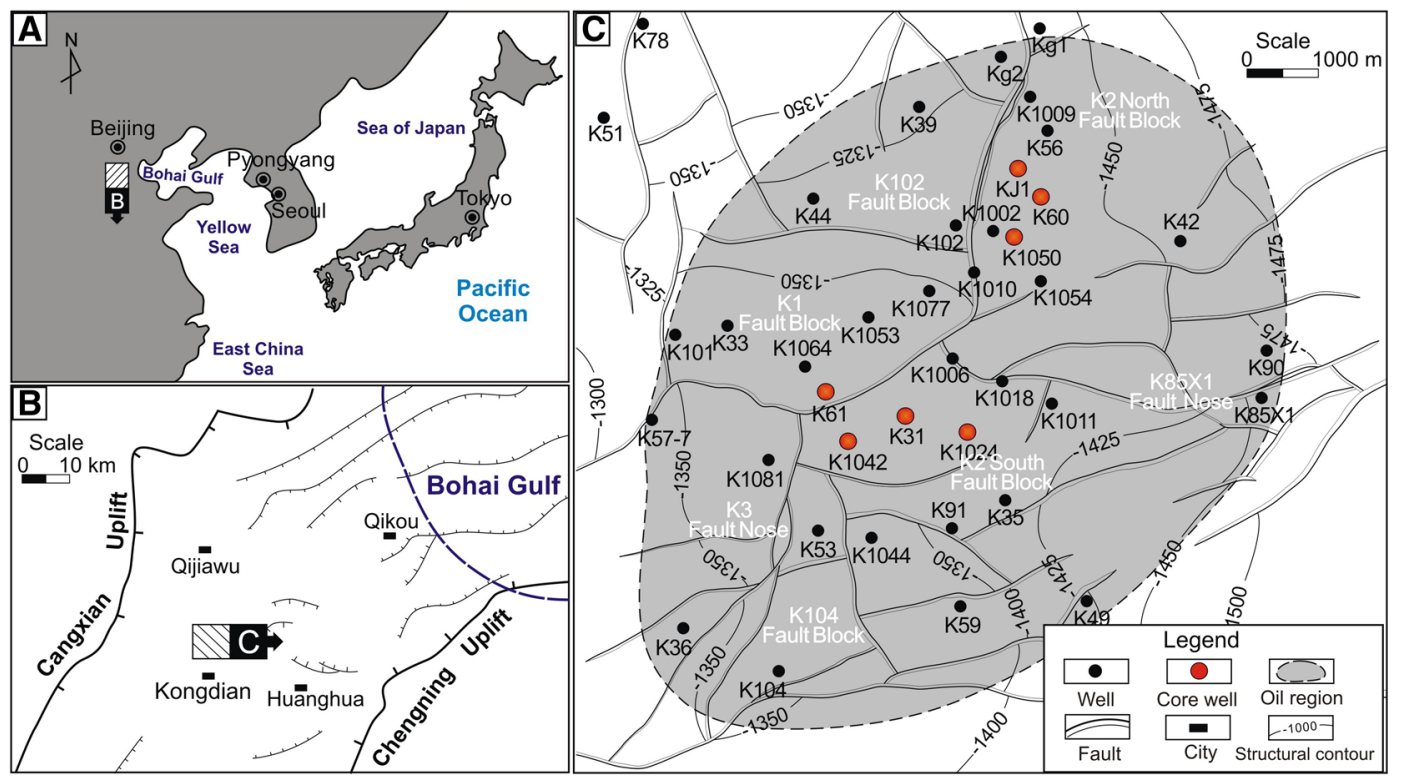

Figure 1. Map of the study area and geological survey of the Kongdian oilfield in the Huanghua depression.

lower Guantao Formation, Kongdian Oilfield (Hou et al. 2008; Wu et al. 2010; Chen et al. 2012). What were the fluvial styles in the upper Guantao Formation? What is the reason that led to change of dominant fluvial styles? With these questions, detailed description of the core data, well logging, $3-\mathrm{D}$ seismic data and correlations of well-logs were used to analyze different fluvial styles and main forcing factor on variations of fluvial styles of the Guantao Formation in study area.

\section{Geological setting}

The Kongdian Oilfield is located in the mid-south area of Huanghua depression which is a significant Cenozoic tectonic unit broadly NE-SW oriented, located in the middle of the Bohai Gulf basin, Eastern China (figure 1). The Huanghua depression contains approximately $5000 \mathrm{~m}$ of Cenozoic alluvial, fluvial, and lacustrine strata. The Huanghua depression underwent multistage extension and subsidence interpreted through the analysis of the tectonic-sequence surface, syn-sedimentary fault's activity and the back-stripping of the subsidence history (Li et al. 2009). The bottom interface of Miocene Guantao Formation is a regional postrifting unconformity surface and divides the basin's Cenozoic evolution into rifting and post-rifting stage. The rifting stage had multiple sedimentary cycles and very thick lacustrine sediments (3500$4000 \mathrm{~m}$ ) formed during this period and several seawater intrusions occurred during this period as well (Qi et al. 1994). In the filling sequence of the rifting stage, the bottom interface of the first member of Shahejie Formation is also a regional recognizable angle $\left(20^{\circ}-35^{\circ}\right)$ disconformity surface in the whole basin and divides the rifting stage into two extensional stages. The geometry feature and property of the fault system shows that the tectonic deformation of the study area was controlled by the NW-SE extending stress field in the rifting extensional stage I and the extending stress field turned to NS in the extensional stage II (Qi et al. 2010; Ye et al. 2013). The multistage extension and subsidence process is closely related to the change of the regional extending stress field orientation which was controlled by the tectonic events of the surrounding plates, especially the accelerated westward subduction from the Pacific plate to the Eurasia plate (Li et al. 2011). In the post-rifting stage, the middle and north area of Huanghua depression underwent stable subsidence at early stage and accelerated subsidence at late stage. In the Miocene, the Guantao Formation which was deposited during the stable subsidence period is composed of coarse clastic sediments dominated by fluvial facies (He et al. 2008) and the depth of the Guantao Formation ranges between 1350 and $1500 \mathrm{~m}$ in study area (figure 2). The southwestern Cangxian paleo-uplift were considered to be main source areas of Guantao Formation in Kongdian oilfield through the cluster analysis of the heavy mineral associations and ZTR index analysis (Sun et al. 2006) (figure 3). 


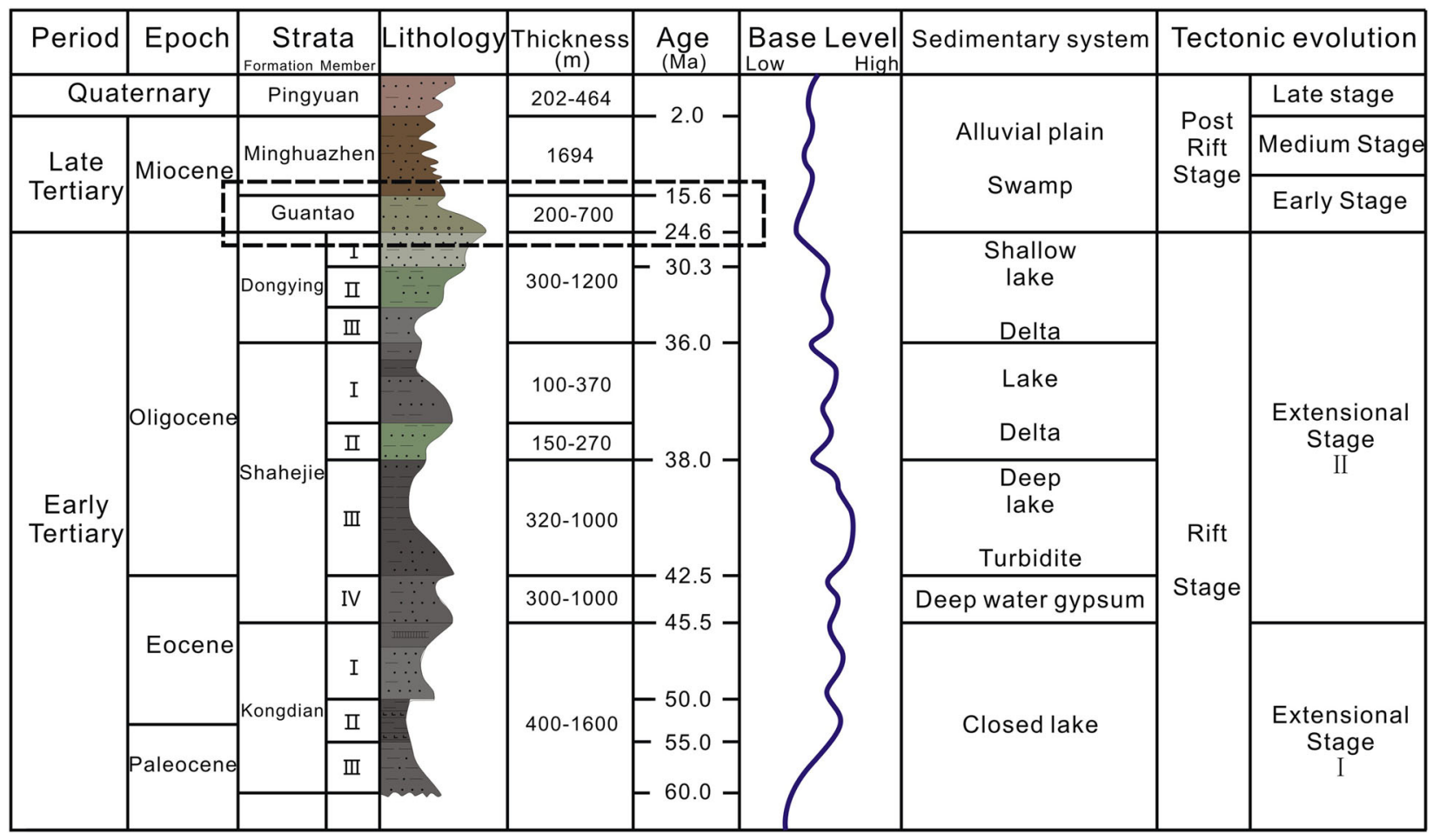

Figure 2. Comprehensive geology column of study area. The study interval, highlighted by a black box, is located in the Guantao Formation.

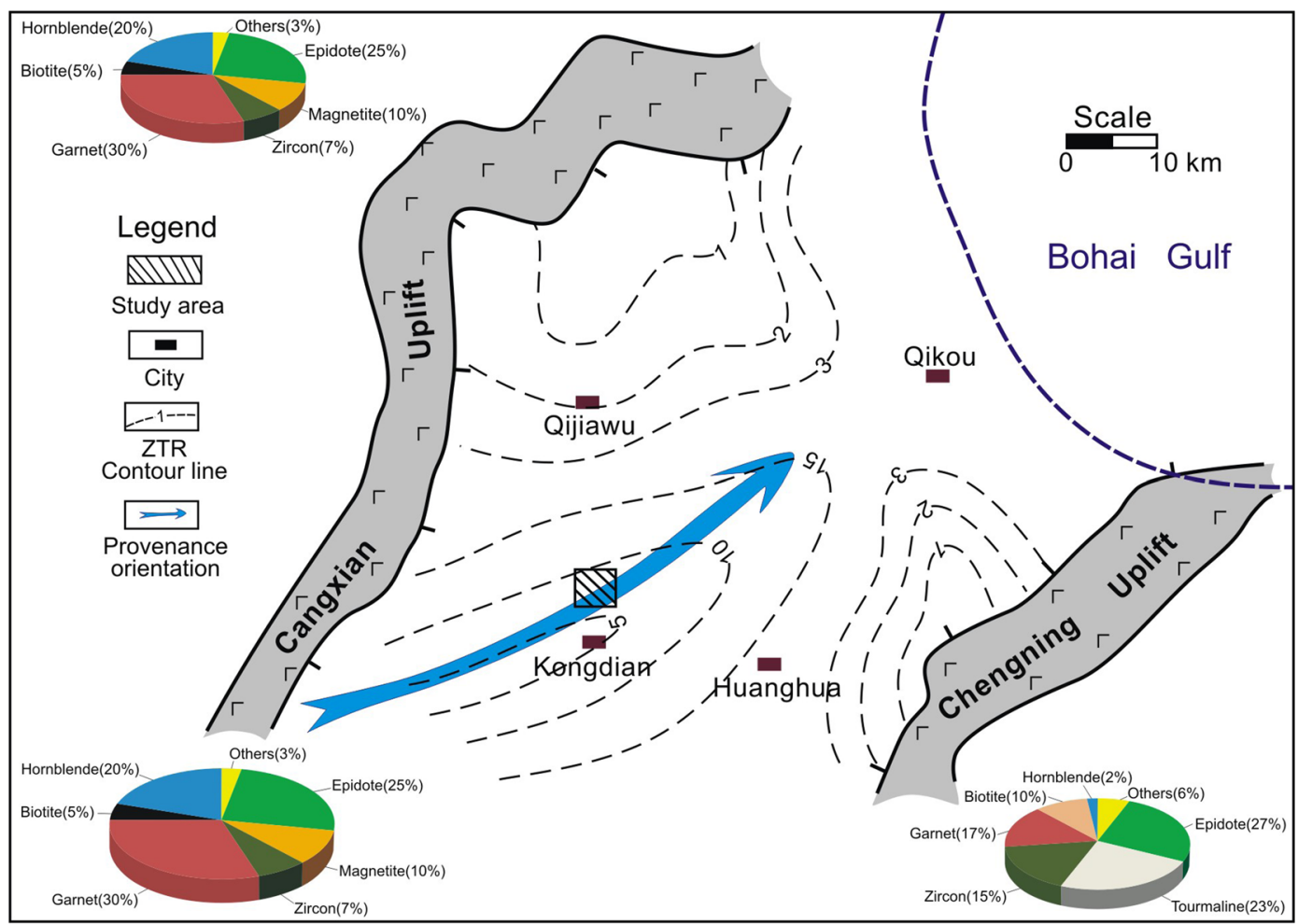

Figure 3. Direction of sediment supply in Kongdian Oilfield obtained from the study of heavy mineral assemblage types and ZTR. 
Table 1. Basic data of wells used in the study.

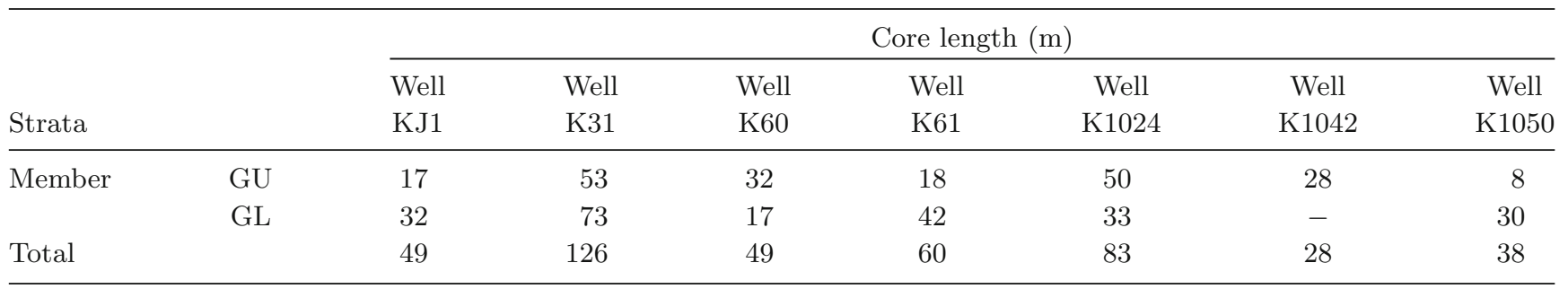

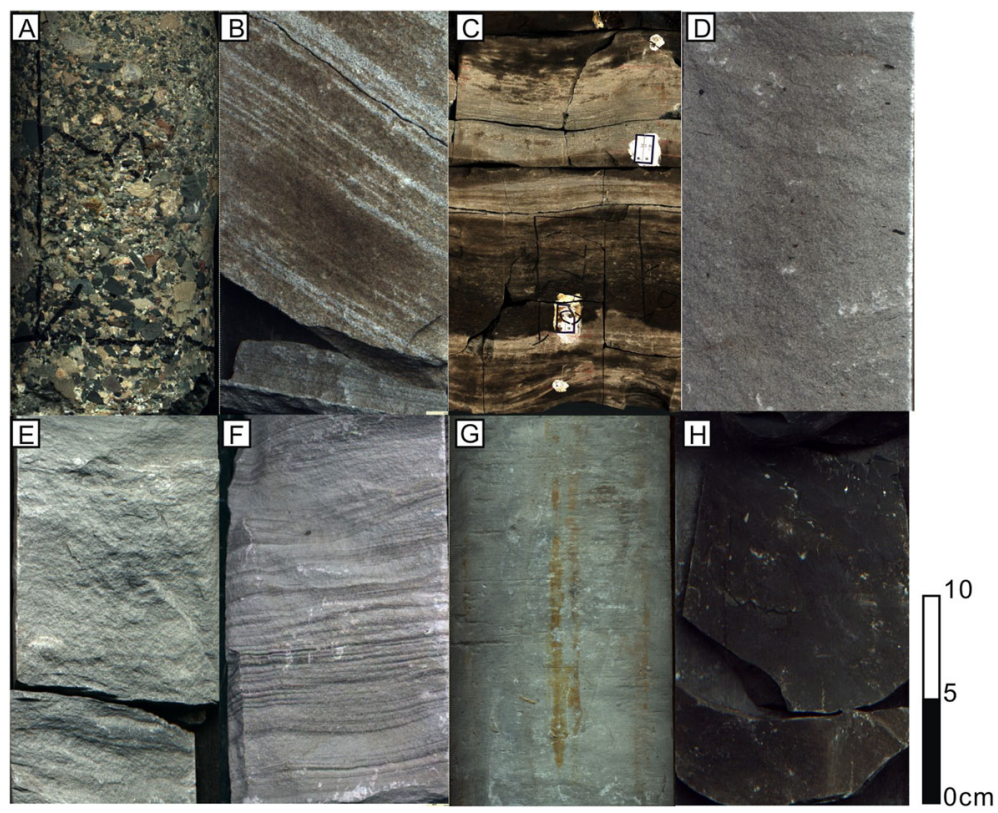

Figure 4. Photographs of lithofacies from the study area.

\section{Methodology}

An integrated data set from Kongdian oilfield was used to address the goals of this study including 7 wells with cores, more than 150 wells of logging and a 3D seismic data set acquired over an area approximately $5.5 \times 5 \mathrm{~km}$. These wells are listed in table 1. The cores used are from the Guantao Formation. The total length of the cores is $433 \mathrm{~m}$. Some core photographs are also used in the study of depositional environments. Descriptive content based on the core includes grain size, colour, sedimentary structures and so on. Spontaneous potential (SP) and gamma-ray (GR) log are used as auxiliary tools to identify facies. 3D seismic stratal slices are also used to predict the plane distribution of fluvial deposits which improves seismic-surface display mainly by making slices linearly between geologic time-equivalent seismicreference events (Zeng et al. 1998a,b). Successive reference horizons (top and bottom interfaces of Guantao Formation) were spaced at $110 \mathrm{~m} \mathrm{sec}$ intervals and stratal slices were generated at $2 \mathrm{~m}$ sec intervals. Reconnaissance horizon slicing was accomplished using multiple reference horizons, each having been chosen for its reflection continuity. Each horizon slice represented an amplitude extraction from a level at a fixed interval below or above the reference horizon. On stratal slices, Channel belts fills are defined by strongly positive (red) amplitudes that indicate well-developed sandstones. Weakly positive amplitude denotes thin or shaly sandstones and negative amplitude (blue) corresponds to mudstones. Through the comprehensive analysis and classification of information from core, logging, and seismic data, facies in the study area were identified and the depositional environment was deduced.

\section{Lithofacies, facies associations and fluvial styles}

\subsection{Lithofacies}

Eight lithofacies are defined based principally on grain size and sedimentary structures in the 
Table 2. Facies classification and descriptions of the Guantao Formation from the study area.

\begin{tabular}{|c|c|c|}
\hline Lithofacies & Description & Interpretation \\
\hline Gc: Clast-supported conglomerate & $\begin{array}{l}\text { This lithofacies consists of } \\
\text { clast-supported normally graded } \\
\text { conglomerate. Bone clasts that form } \\
\text { thick, poorly sorted clast-supported } \\
\text { beds with interstitial sand }\end{array}$ & $\begin{array}{l}\text { Bedload deposition in the environment } \\
\text { of rapid flow-speed-reduction. This } \\
\text { lithofacies contain lag deposits from } \\
\text { rapidly waning flow }\end{array}$ \\
\hline Sp: Planar cross-bedded sandstone & $\begin{array}{l}\text { Light green medium to fine sand, well } \\
\text { sorted with relatively high angle } \\
\left(25-30^{\circ}\right) \text { cross stratification, covered } \\
\text { by } \mathrm{Sr}, \mathrm{Mm} \text {. This type of lithofacies is } \\
\text { very common in this area }(32.2 \%) \text {. } \\
\text { Basal erosion surface has been } \\
\text { observed frequently }\end{array}$ & $\begin{array}{l}\text { Generally deposited in the lower part of } \\
\text { sand bodies with overlying mud rock } \\
\text { bedload deposits from linear or } \\
\text { slightly sinuous dunes forming in the } \\
\text { deep or fast-flowing part of the } \\
\text { channel }\end{array}$ \\
\hline St: Trough cross-bedded sandstone & $\begin{array}{l}\text { Light green medium sand with } \\
\text { cross-bedded troughs, well sorted, } \\
\text { generally observed in the lower parts } \\
\text { of sand bodies }\end{array}$ & $\begin{array}{l}\text { Interpreted as the product of the } \\
\text { migration of sinuous-crested dunes in } \\
\text { the deep part of the channel }\end{array}$ \\
\hline Sm: Massive sandstone & $\begin{array}{l}\text { Massive, poorly sorted to weakly } \\
\text { graded, light grey, medium to fine } \\
\text { sandstone. Occasionally contains } \\
\text { carbonaceous floating pebbles }\end{array}$ & $\begin{array}{l}\text { Deposited in the channel by rapidly } \\
\text { waning fluvial flows }\end{array}$ \\
\hline Fm: Massive siltstone & $\begin{array}{l}\text { Massive grey green siltstone or sandy } \\
\text { siltstone, poorly sorted, often } \\
\text { interbedded with mudstone and rarely } \\
\text { observed in channels. It has a } \\
\text { relatively flat base }\end{array}$ & $\begin{array}{l}\text { Deposition occurred in rapidly waning } \\
\text { flows farther from the channel where } \\
\text { flows were not sufficiently powerful to } \\
\text { scour the floodplain substrate }\end{array}$ \\
\hline Fr: Ripple cross-laminated siltstone & $\begin{array}{l}\text { Light grey or dark grey, ripple } \\
\text { laminated siltstone, well sorted, } \\
\text { ooccasionally contains fine to very fine } \\
\text { sandstone. Slightly erosional base can } \\
\text { be observed. The top surface is often } \\
\text { eroded by the new elements in the } \\
\text { upper part. Sometimes observed as an } \\
\text { independent strip sand body }(<1 \mathrm{~m}) \\
\text { in mudstone }\end{array}$ & $\begin{array}{l}\text { This lithofacies is interpretable as } \\
\text { bedload deposition in unidirectional } \\
\text { flows or abandoned channel fills }\end{array}$ \\
\hline Mm: Massive mudstone & $\begin{array}{l}\text { Grey-green or brown mudstone, massive } \\
\text { or weakly bedded, up to several } \\
\text { centimetres in thickness, abandoned } \\
\text { channel or floodplain }\end{array}$ & $\begin{array}{l}\text { This lithofacies is created by suspension } \\
\text { deposition, formed in the upper parts } \\
\text { of channel sand bodies or in floodplain }\end{array}$ \\
\hline Mc: Carbonaceous mudstone & $\begin{array}{l}\text { Carbonaceous mudstone. Mudstone } \\
\text { with a high carbon content, massive } \\
\text { or horizontally bedded }\end{array}$ & $\begin{array}{l}\text { This lithofacies is interpreted to have } \\
\text { formed from peat swamps in a warm } \\
\text { and humid climate }\end{array}$ \\
\hline
\end{tabular}

Kongdian Oilfield. These are divided into four main groups based on grain size: conglomerates $(G)$, sandstones $(\mathrm{S})$, siltstones $(\mathrm{F})$, and mudstones $(\mathrm{M})$. Photographic examples and descriptive characteristics of each lithofacies are respectively presented in figure 4 and table 2.

\subsection{Facies associations}

Eight lithofacies have been grouped into seven facies associations. These seven facies associations represent the predominant depositional forms in fluvial environments of the Guantao Formation and major changes in the lithofacies and facies associations of the Guantao Formation were recognized in the study area (figures 5 and 9).

\subsubsection{FA1: Upward-fining channel}

Upward-fining channel is common in the Kongdian Oilfield (figure 5A). Gc frequently appears at the bottom of the single channel sand bodies 


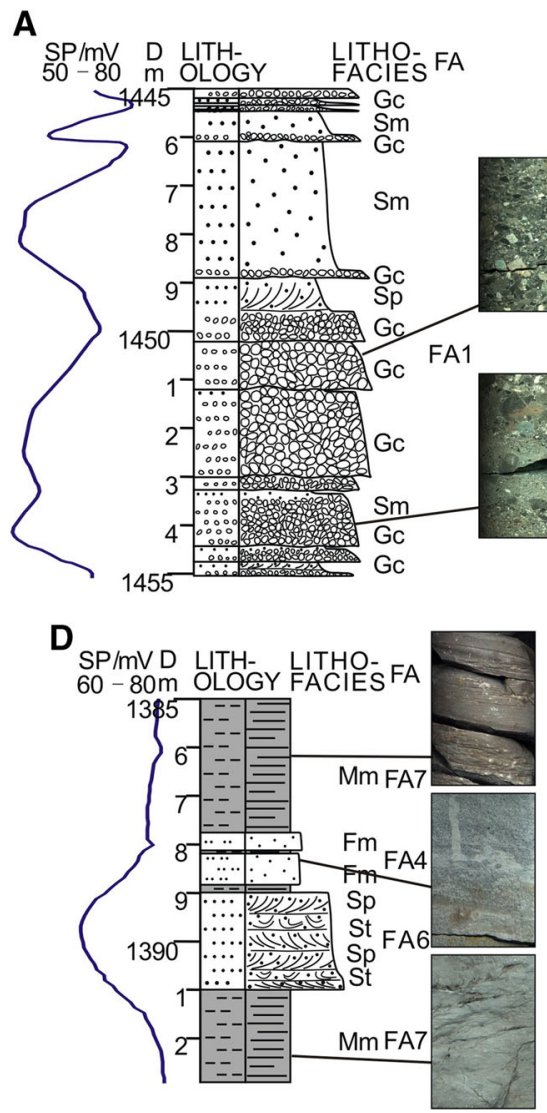

\section{B}
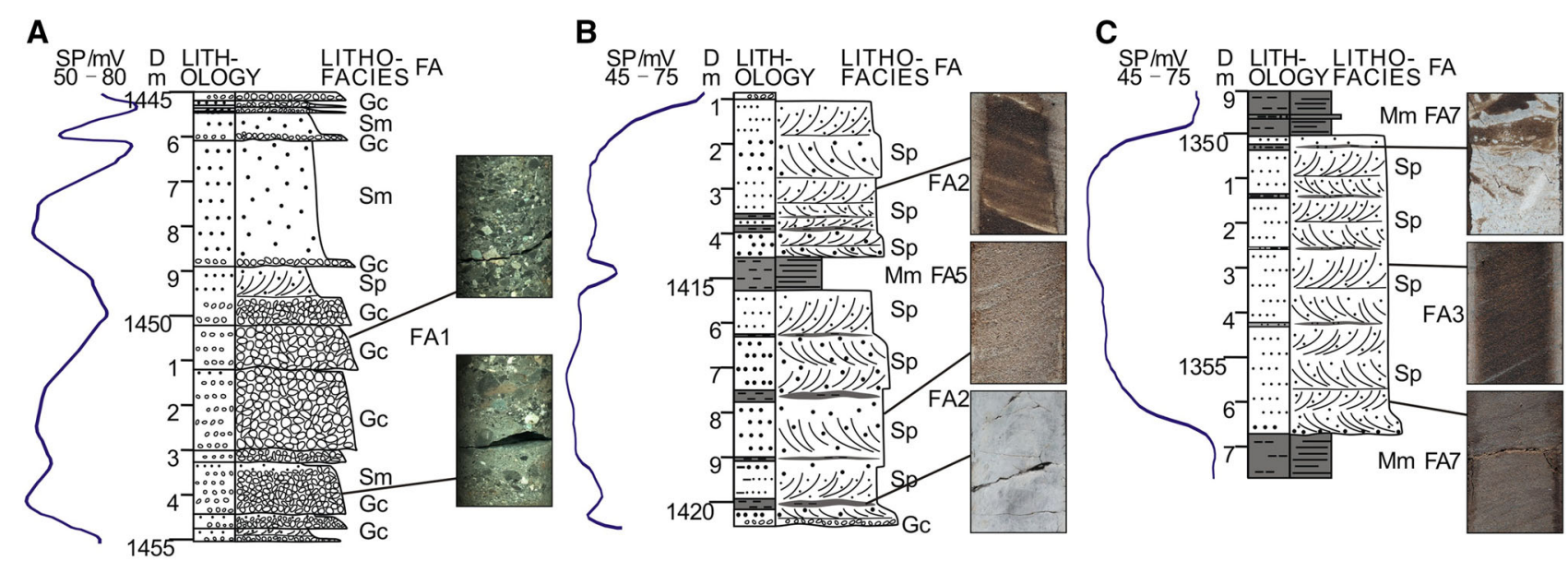

\section{E \\ SP/mV D LITH-
$55-70$ IITHO-}
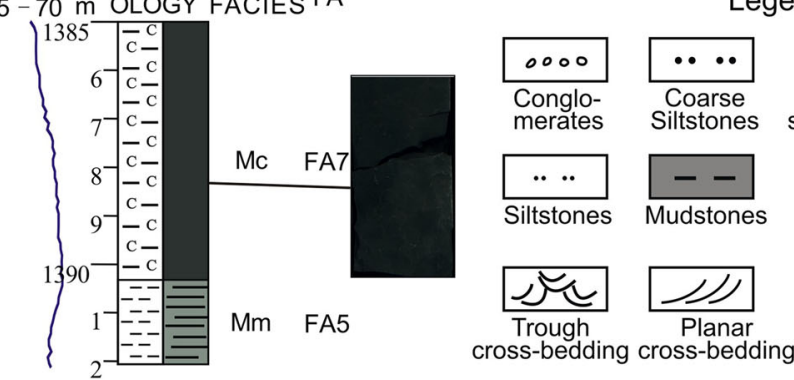

Legend

Figure 5. Photograph of core and typical vertical log of facies associations.

vertically, covered by $\mathrm{Sm}$, Sp. The upper part contains $\mathrm{Sr}$ and Fr, and Fm. The bottom conglomerate is characterized by imbricate arrangement. The grain size of the channel sand bodies is fining-upward. Upward-fining channel fills commonly show fining-upward successions and this feature can be observed from the core and logging curve. Several scour interfaces may exist in channel sand bodies reflecting multistage paleo-flood events (Allen 1983). This group of facies may be traction-load deposits laid down within the active channel.

\subsubsection{FA2: Braided channel with mid-channel bar}

Braided channel with mid-channel bar is another important facies association in this area, with coarse grain size clastic. Thin clast-supported conglomerate is at the basal part, and the middle and upper part is planar cross bedded coarse to medium sandstone with slight fining in grade. More than one thin muddy layer can be observed in the mid-channel bar (figure 5B). This facies association is occasionally in contact with rippled sandstone above an erosional surface. Almost unchanged granularity vertically in sandstone of this element reflects the rapid filling deposition in the channel. It is frequently developed in the member GL. These deposits were laid down by channelized, predominantly unidirectional flows (figure 12) in which sediment was transported chiefly as bedload, producing macroscale bedforms (Allen 1983; Bridge 1985; Miall 1985; Liao et al. 1998).

Facies analysis on stratal slices can reduce the ambiguity and it also helps to predict the plane distribution of sediments. Amplitude band commonly occur in the reservoir body outline. The amplitude image of GL shows several wide reservoirs that are typically more than $2000 \mathrm{~m}$ wide which are reflected as strongly positive amplitude bands (figure 6). These reservoirs are interpreted as wandering channel (braided channel) sandstones which is a kind of channel sandstones typically with large coverage area. Several scattered irregular areas with strongly positive amplitude can be observed on stratal slice of GL and these areas are interpreted as mid-channel bars in braided channel combining the analysis of well data. The deposits of mid-channel bar is thick and the spontaneous potential curves show box-shaped signature. 

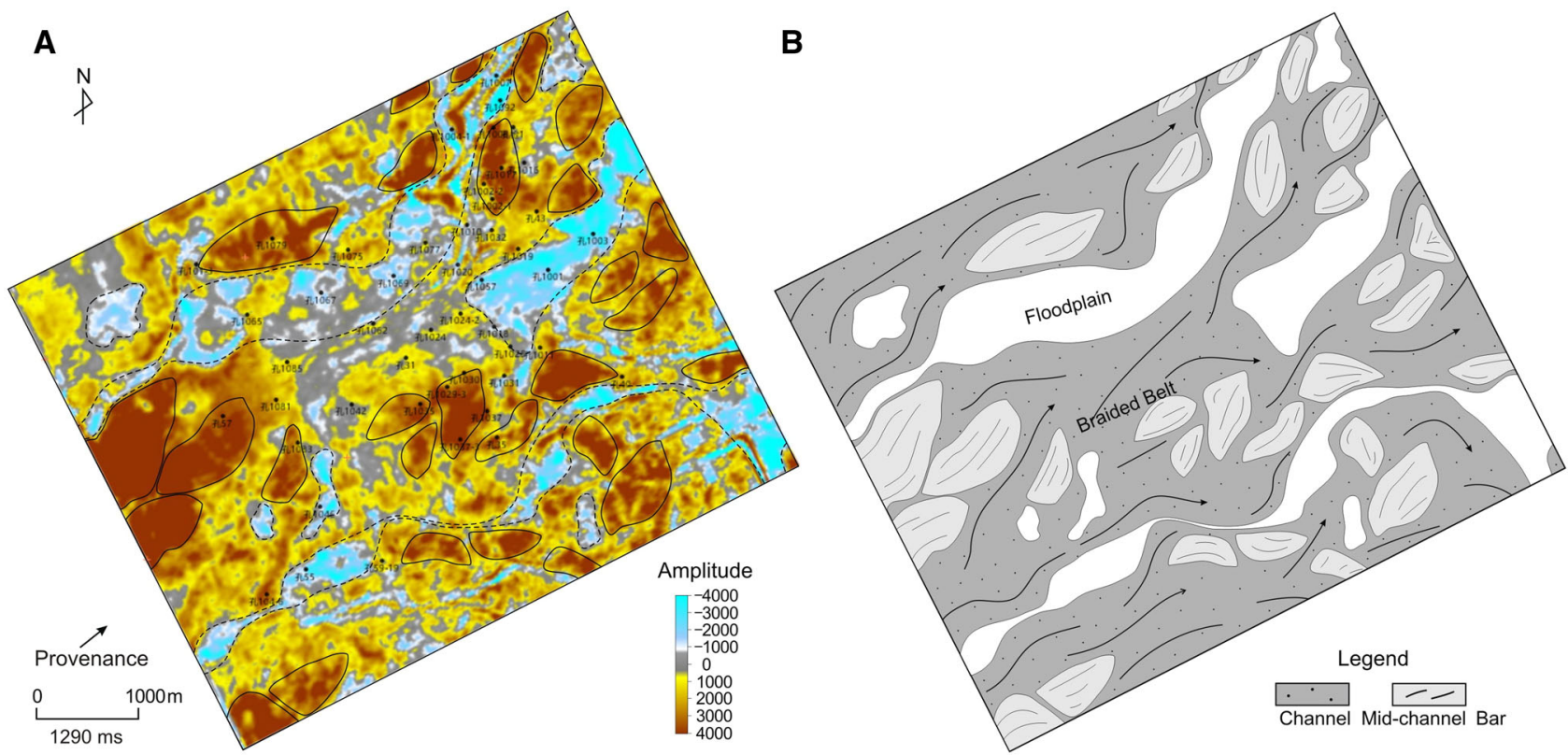

Figure 6. Typical stratal slice and sedimentary interpretation of GL in Kongdian oilfield.

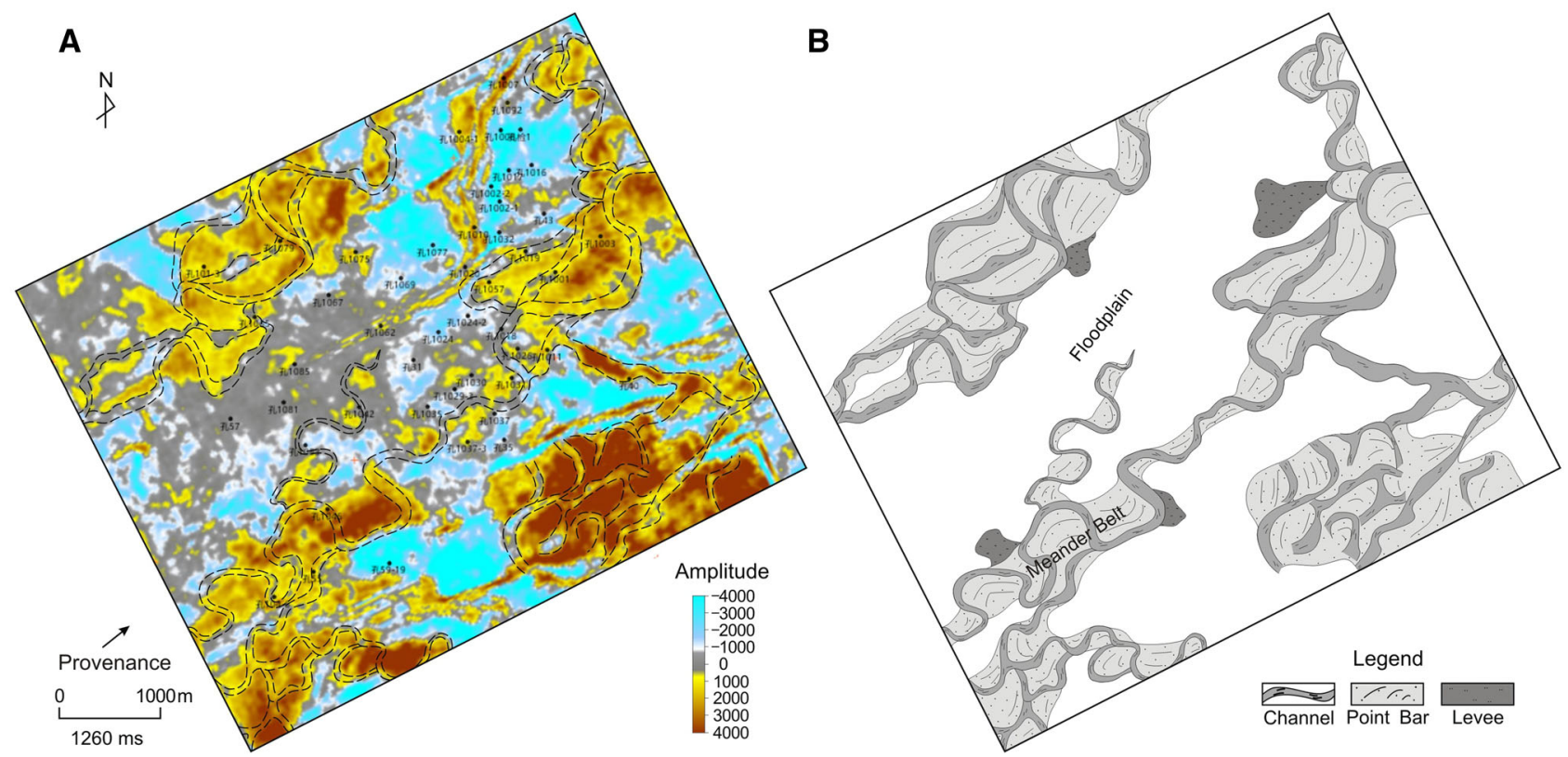

Figure 7. Typical stratal slice and sedimentary interpretation of GU in Kongdian oilfield.

\subsubsection{FA3: Meandering channel with point bar}

FA3 is a common facies association in GU. Planar cross bedded medium-fine sand deposited in the lower part of sand bodies. The upper part is the deposition of rippled fine sandstone or siltstone. The grain size of the sand body is fining upward. A number of erosion surfaces can be observed inside the sand body reflecting multiple reactivation events. The thickness of a single story is related to the duration of the flood and the sediment loads that floodwater carried. The story is $2-3 \mathrm{~m}$ thick and has a low dip angle $\left(<5^{\circ}\right)$ in this area (figure $5 \mathrm{C}$ ). Complex paleocurrent directions reflected that these channels probably deposited in the meandering river system (figure 12). The main flow of the channel is directed away from the inner bank, as on the inside of a meander, surface flow impinges on the outer bank, leading to an active cut bank erosion, and traction-load deposited in the inner bank (Miall 1985). 

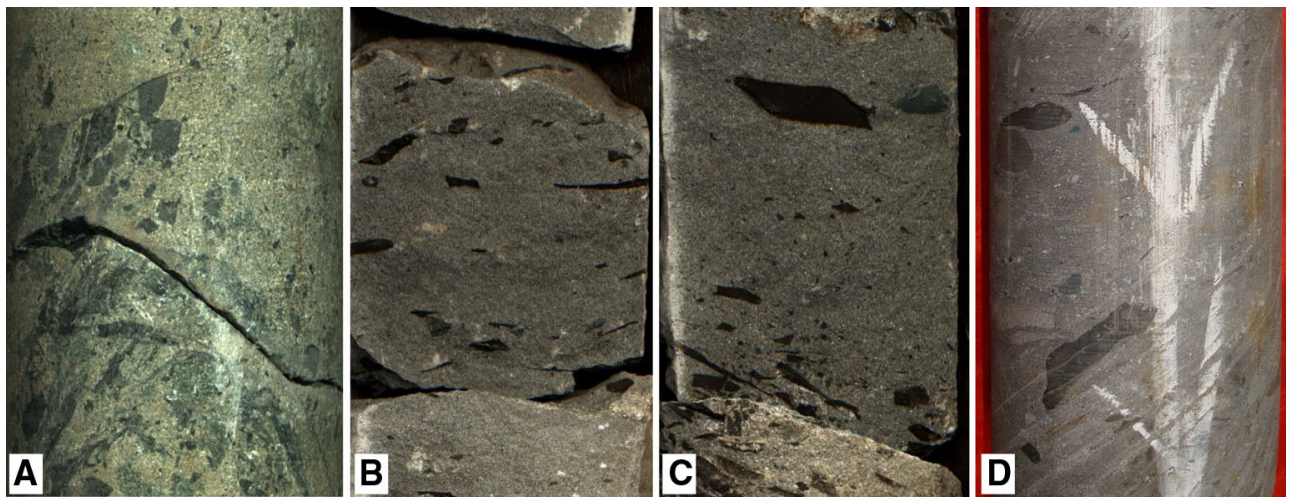

Figure 8. Photographs of carbonaceous floating pebbles from the swamp in the GU.

The amplitude image of GU shows several relatively narrow reservoirs that are typically 300$800 \mathrm{~m}$ wide (figure 7). The amplitude bands in the GU sands which have a channel-like form are thought to represent successive positions of the meandering belt as it migrated laterally prior to abandonment. Sinuous channels interpreted as abandoned channels following periods of point-bar deposition can be observed on thick sandstone belts in GU. Amplitude images show sinuous trends of the abandoned channels. These abandoned channels commonly are moderate to high sinuosity, 50-100 m wide. The channels locally oscillate laterally and cut back locally across preexisting point bars and resulting in complex internal reservoir architecture.

\subsubsection{FA4: Levee}

The grain size of levee deposits is fine, mostly siltstone and sandstone. The sedimentary structures are mainly massive and ripple lamination. This facies association is interbedded with channel or floodplain vertically (figure 5D). This type of deposition may develop on both sides of the river. The levee deposits are not often preserved due to the erosion of the frequently migrating river. This element is rarely observed in the lower part of member GL, and frequently observed in the member GU (figure 7). These over bank deposits is product of splaying processes where the mass over bank flooding produced sheet-like deposits and built the levee (Allen 1983; Miall 1985; Fielding 1986).

\subsubsection{FA5: Floodplain}

Floodplain deposits formed in low-energy environment during flood period are particularly important components of GU meandering rivers characterized by broad floodplains (48.5\%). The floodplain deposits are mainly massive mudstone with internally developed silty thin layers, and can be up to tens of metres thick (figure 5D). Relatively coarse-grained braided rivers of GL have channel systems that tend to occupy most of the river floodplain, so that floodplain are small in area and their deposits constitute a minor component of the fluvial assemblage (figure 6).

\subsubsection{FA6: Minor channel in floodplain}

These channel-like sedimentary bodies are filled by thin planar cross-bedded sandstones or trough cross-bedded sandstones basal covered by thick massive siltstone or mudstone. These fine particles reflected the insufficient supply of sediments adjacent to active channels (figure 5D). These small-scale channel fills were interpreted as the fill of the minor channel segment in floodplain.

\subsubsection{FA\%: Swamp}

The dark grey carbonaceous mudstone is the main lithofacies of swamp deposits, weakly bedded, (figure 5E). Carbonaceous floating pebbles $(3-5 \mathrm{~cm})$, observed in channel fills occasionally (figure 8), were derived from cannibalization of swamp deposits. These deposits are probably formed in a low-lying area in the flood plain where the water gathered easily and plants are easy to grow.

\subsection{Fluvial styles}

The stratigraphic record of the Guantao Formation in the Kongdian Oilfield consists of a $120 \mathrm{~m}$ thick succession with two distinctive fluvial packages (figures 9-11). The lower package is a 


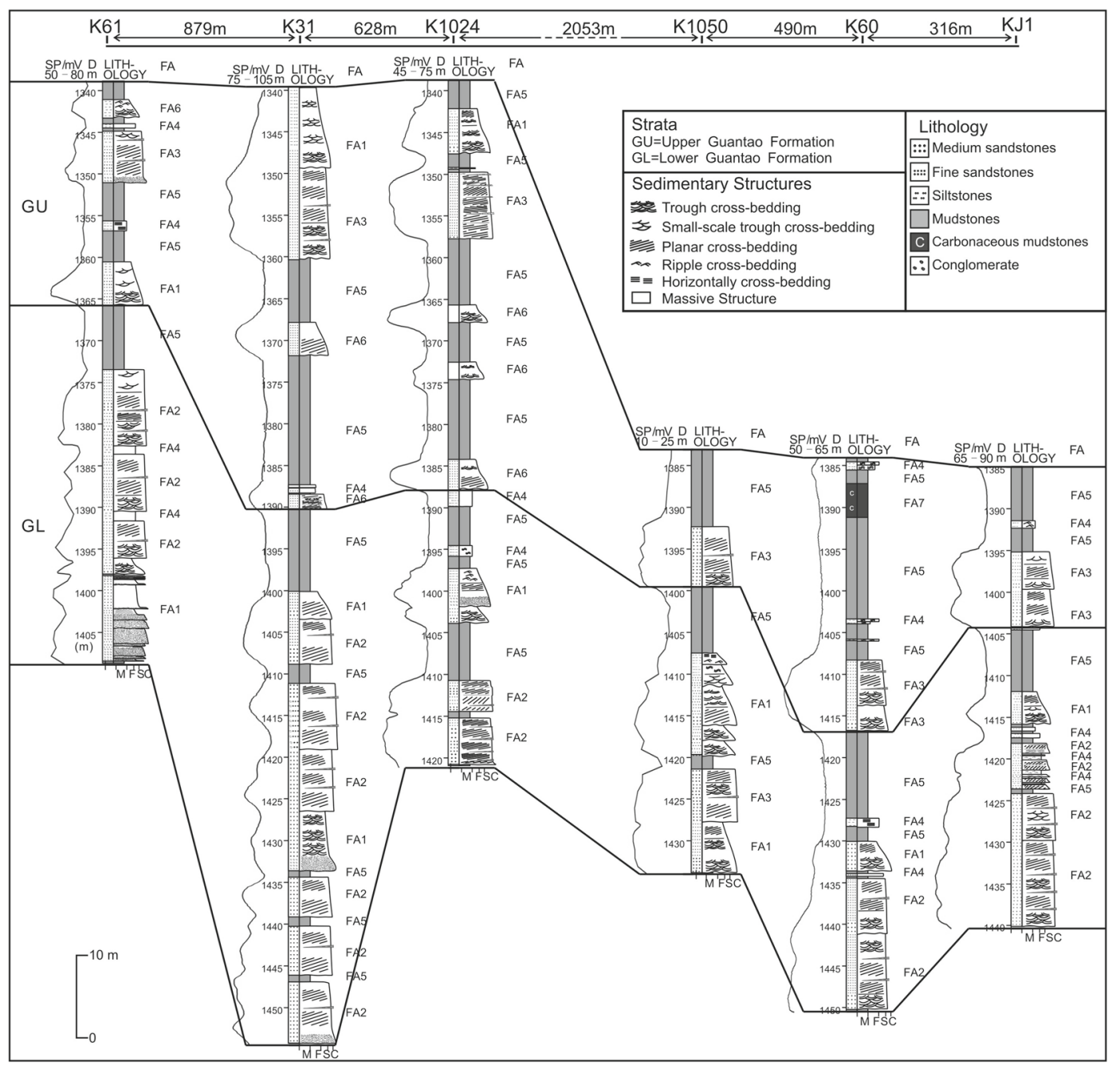

Figure 9. Fluvial lithofacies assemblages and vertical profiles of coring wells in study area.

coarse-grained succession dominated by braided channels sand bodies $(\mathrm{W} / \mathrm{Th}>100)$ (figures 9 and 10). The braided fluvial style is characterized by very thick sandstone, up to $70 \mathrm{~m}$ or more. This fluvial style was observed in the member GL which contains a medium-fine grained succession of sandstones ( $70 \%$ in vertical $\operatorname{logs}$ and $83 \%$ in cores). The thick sand body, which is often separated by thin layers of fine grained deposit, is actually multiple stacked mid-channel bar sand bodies in the channel with paleocurrents directed to the NE and NNE (figure 12) (Straub et al. 2009). There is no obvious sequence of grain size variation in the sand body and the coarsest deposits are not necessarily confined to the bottom. The scale of the levee may be very small in the braided river sedimentary system so that silty and muddy deposits are relatively rare, reflecting the probable lack of suspended sediment in the ancient braided river in this area.
The only small amount of suspended sediment could well be quickly scoured away by the frequent migration of the channel. The upper package of member GU contains a fine grained succession of mudstones (45\% in vertical $\operatorname{logs}$ and $48.5 \%$ in cores) with isolated, relatively narrow $(\mathrm{W} / \mathrm{Th}<70)$ high-sinuosity fluvial channels (Gibling 2006). Compared with the GL, floodplain is preserved relatively well with the content of $48.5 \%$ in this member (figure 9). Sand body is connected with the underlying floodplain mudstone through scour surface (figure 10). The scour surface, in turn, are followed by the lithofacies Sp, St and Fr. The upper part of the sequence is massive mudstone of floodplain. The thickness of complete vertical sequence of a meandering channel ranges between 5 and $10 \mathrm{~m}$ in this area. These sand bodies are mainly point bar sand bodies in the channel with complex paleocurrent directions (figure 12). Thin layer of siltstone or mudstone between the small rhythms 


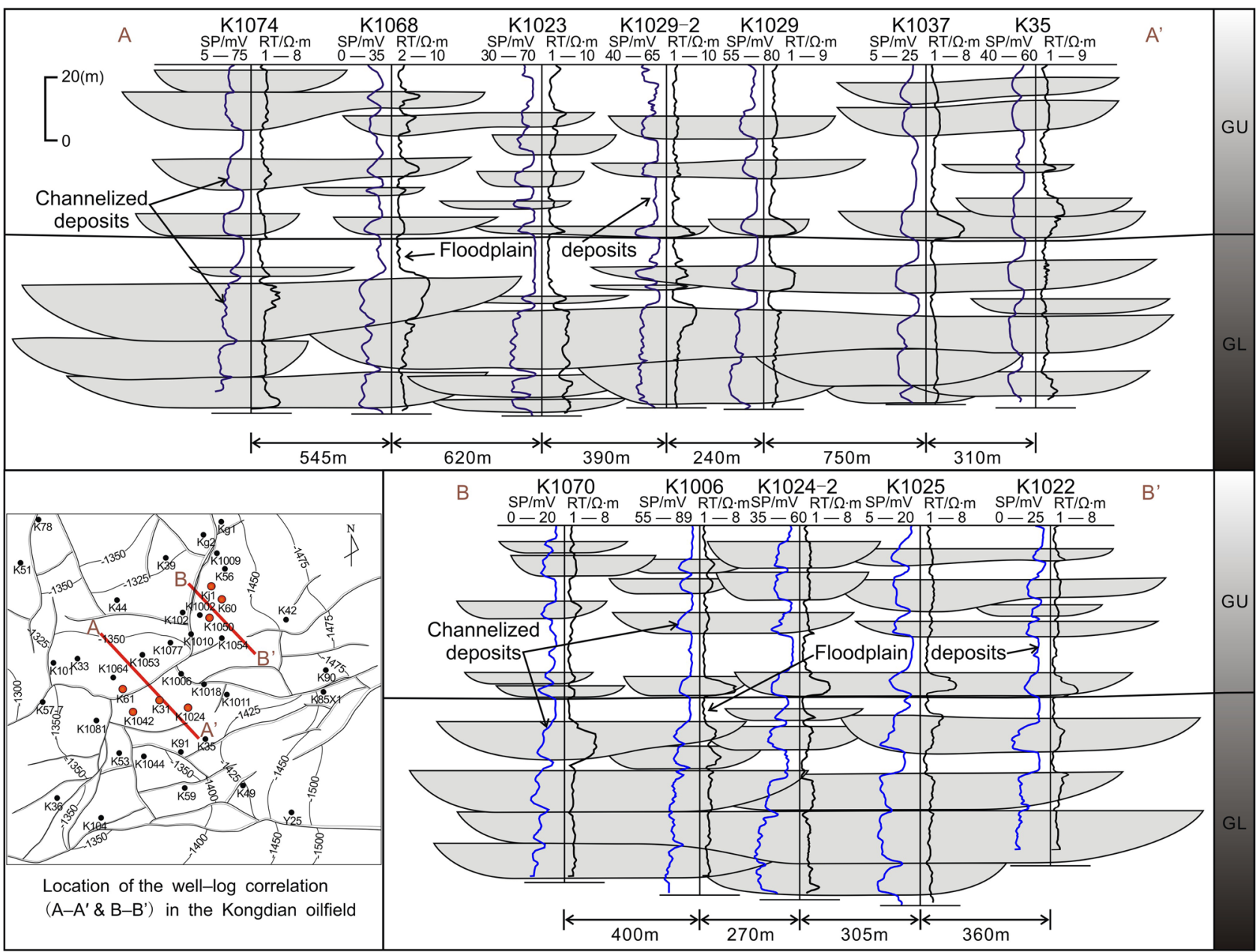

Figure 10. Section from K1074-1 well to K1072 well.

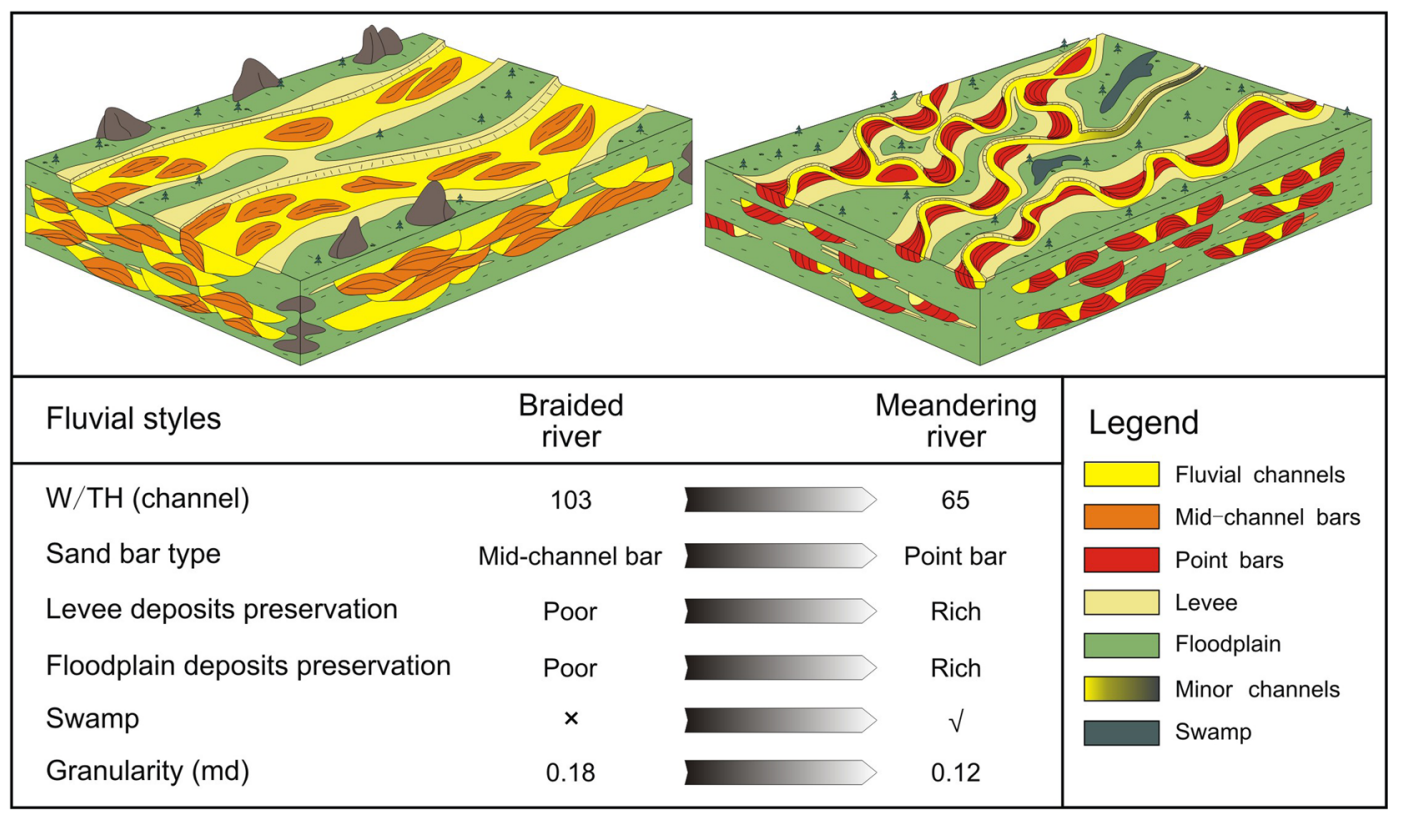

Figure 11. Model of three different rivers identified in the Guantao Formation study area. 

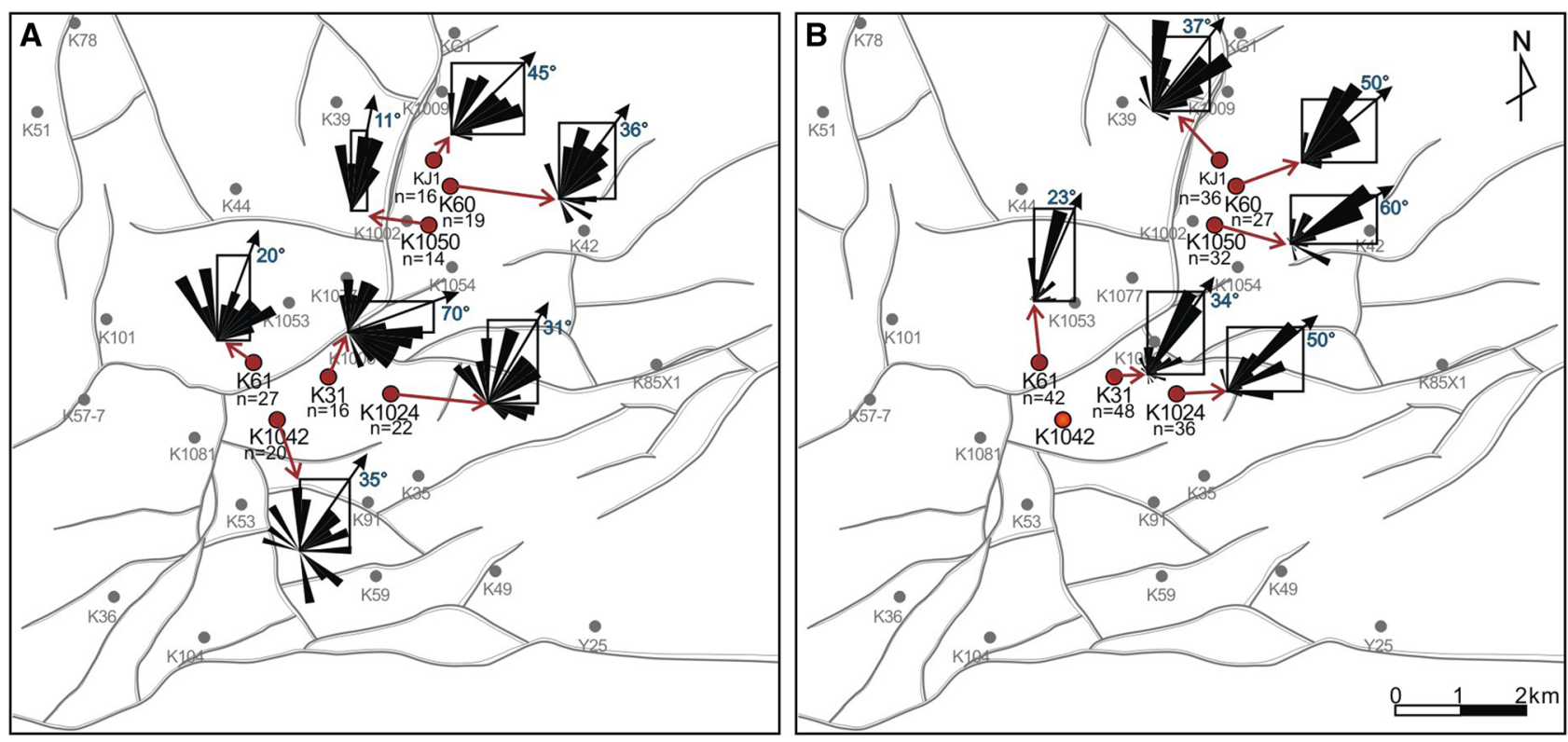

Figure 12. Paleocurrent directions in the upper (A) and lower (B) Guantao Formation obtained from the study of diplog.

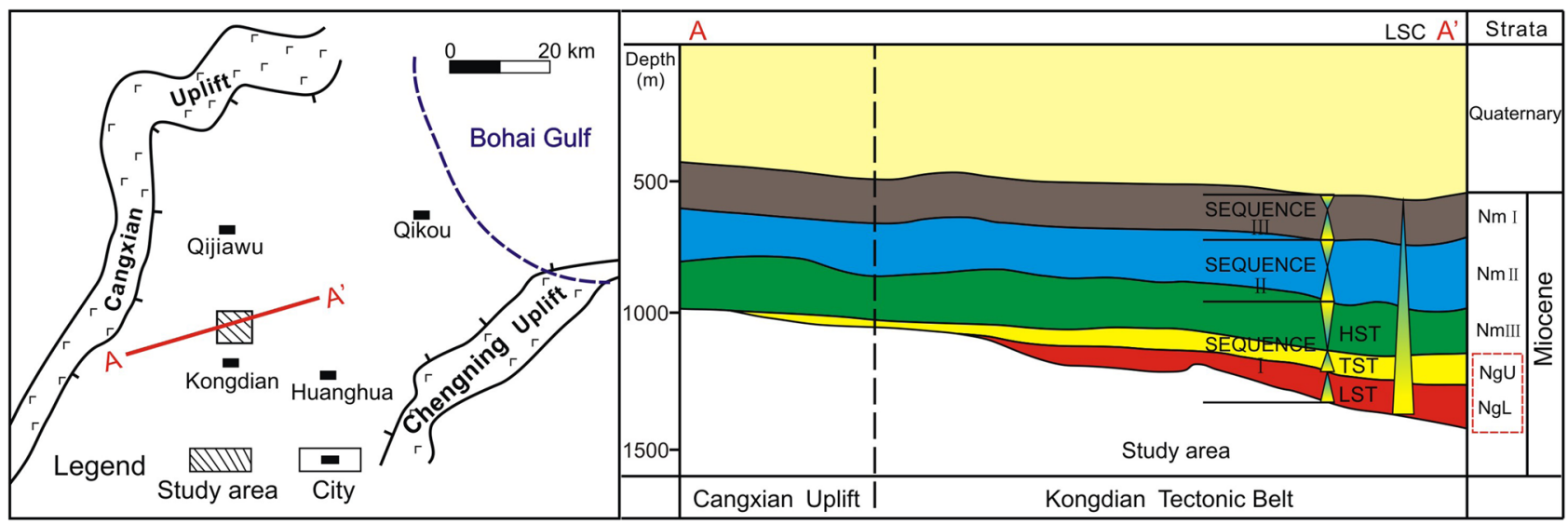

Figure 13. Sequence stratigraphic interpretation of seismic profiles in the Cangxian-Kongdian area of the Huanghua depression.

deposited reflected the deposits in the normal water period (Yue 2006). Levee may be better preserved in the inner bank but poorly preserved in the cut bank due to the lateral erosion of the channel.

\section{Discussion}

\subsection{Forcing factor}

To determine the influence of forcing factor on fluvial style transformation of the Guantao Formation, this research has been carried out regarding the potential factor base level changes.
The Guantao Formation is composed of lower LST mainly consists of multi-storey, large-scale channel sandstones which are related to low rates of base-level rise (figure 13). In contrast, the upper part of the Guantao Formation is a TST comprises single-storey strata with relatively smallscale channels, which were probably associated with more rapid rates of base-level rise. In the study area, the Guantao Formation is unconformably underlain by the Dongying Formation without incised valley. The evidence from oilfield show that the change of scale and styles of channel most likely reflected the changes of baselevel rise. The sediments were deposited in an overall fining-upward and transgressive sequence. 

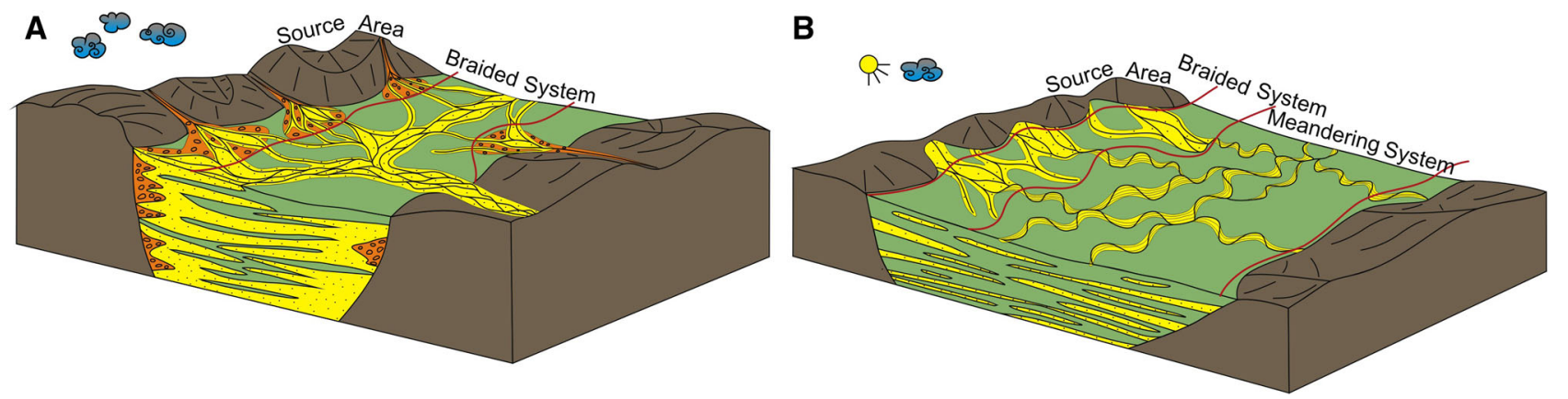

Figure 14. Paleogeographic reconstruction of the Guantao Formation.

Variation in base level must be related to continuous tectonic subsidence and uplift of the Bohai Gulf basin during the post-rift stage.

Greater content of fine particles in stratigraphic section are interpreted as a relative lower altitude and further source area caused by the extension and subsidence of the basin. The large scale of sand bodies and high sandstones content of the lower part of Guantao Formation reflect the adequate sediment supply and the closer source area at the early post-rift stage. With the further development of tectonic movement, decrease in sediment supply capacity resulted into finer grain size and the less sandstone proportion (51.5\%) of the upper part of Guantao Formation.

Besides, analysis of sporopollen and mudstone in the Kongdian area indicates that the transition from wet to semi-arid climate in the Guantao Formation is also a potential influence factor of fluvial style transformation (Li et al. 2011).

\subsection{Sedimentary evolution model}

The depositional model of the early sedimentary stage fluvial system of Guantao Formation is best represented by a wide channel belt, internally showing a braided morphology of minor channels. The position of the active channel belt vary through time as the channel belt aggrades. Average rates of vertical accretion were high throughout lower Guantao time for the large number of major channels preservation within the section. The close vertical spacing and large width of channel is interpreted to be the product of lower subsidence rate which gave opportunity for rivers to laterally migrate and expand. The complex internal arrangement of sandstone lenses within the GL channel sequences resulted from the rapid switching of channels and the downstream migration of low relief barforms. High degrees of channel belt interconnectedness would suggest relatively high rates of average sediment accumulation and the channels were actively transporting much coarser grained material. Braided channel-fill sequences typically terminate upward either with deposition of fine silt and mud or laterally extensive irregular scour surface. As for GU, the isolated channel-belt within a fine-grained succession of mudstones reflects deposition by relatively small, sinuous rivers that deposited sand in point bars. The channel migrated laterally within its channel belt and produced truncated point-bar. A relatively high rate of subsidence is interpreted during the deposition of the meandering channel belt as levees are better preserved compared to GL. Overbank flooding produced splays attached to some channel fills forming a levee. Channelized deposits represent a relatively low proportion of the stratigraphic sections and floodplain deposits are common (figure 14).

\section{Conclusion}

1. Based on stratigraphic analysis of Guantao Formation, eight lithofacies and seven lithofacies associations have been defined and regional sedimentary evolution model have been established in different periods. The Guantao Formation of Kongdian oilfield is a $120 \mathrm{~m}$ thick fluvial succession composed of braided, meandering channels with vertically variable preservation of floodplain environments. The lower part of the study area is characterized by braided channels with mid-channel bar and the fluvial succession is $50-70 \mathrm{~m}$ in thickness. Braided channels have characteristics as follows: in general, multistorey channels cut frequently and superpose each other, with conglomerate bed of detention at the bottom. From bottom to top, sand 
body becomes thinner and sand grain size gets finer. The upper part of the study area is characterized by meandering channels with point bar and the fluvial succession is about $60 \mathrm{~m}$ in thickness. Meandering channels have isolated channel-belt, truncated point-bar and a relatively high proportion of floodplain deposits.

2. The transformation in the fluvial styles of the Guantao Formation permits interpretation of two main sedimentary scenarios during the Early Miocene in the Kongdian oilfield: an early, low base-level setting and a late, high baselevel setting. Continuous tectonic subsidence and uplift of the Bohai Gulf basin at the postrift stage controlled the variation in base level and fluvial styles.

\section{Acknowledgements}

The author wishes to thank Prof. Lin from the School of Geosciences (Chinese University of Petroleum) sufficient guidance in the project. The Kongdian project was entirely funded by the China National Petroleum Corporation, which is gratefully acknowledged. Special thanks to Zhang Xianguo, Wang Hongwei, Fu Xiaoliang, Liu Xiaochen, Li jia, Wang Chunwei, Zhang Jianxing and Li Shujing for assistance in the project.

\section{References}

Allen J R L 1983 Studies in fluviatile sedimentation: Bars, bar-complexes and sandstone sheets (low-sinuosity braided streams) in the Brownstones (L. Devonian), Welsh borders; Sedim. Geol. 33 237-293.

Allen J P and Fielding C R 2007 Sedimentology and stratigraphic architecture of the Late Permian Betts Creek Beds, Queensland, Australia; Sedim. Geol. 202 5-34.

Arche A and López-Gómez J 1999 Tectonic and geomorphic controls on the fluvial styles of the Eslida Formation, Middle Triassic, Eastern Spain; Tectonophys. 315 187-207.

Benedetti M M 2003 Controls on overbank deposition in the upper Mississippi River; Geomorphology 56 271-290.

Bridge J S 1985 Palaeochannel patterns inferred from alluvial deposits: A critical evaluation; J. Sedim. Petrol. 55 579589.

Bridge J S 1993 The interaction between channel geometry, water flow, sediment transport and deposition in braided rivers; Geol. Soc. London, Spec. Publ. 75 13-72.

Bridge J S 2000 Geometry, lithofacies, and spatial distribution of cretaceous fluvial sandstone bodies, San Jorge Basin, Argentina: Outcrop analog for the hydrocarbonbearing Chubut Group; J. Sedim. Res. 70 341-359.
Catuneanu O and Elango H N 2001 Tectonic control on fluvial styles: The Balfour Formation of the Karoo Basin, South Africa; Sedim. Geol. 140 291-313.

Chen Y K, Wu S H, Mao P and Zhou F S 2012 Characterization of sandy braided river reservoir configuration; Xinjiang. Petrol. Geol. 33 523-526.

Ethridge F G, Wood L J and Schumm S A 1998 Cyclic variables controlling fluvial sequence development: Problems and perspectives; In: Relative role of eustacy, climate, and tectonism in continental rocks (eds) Shanley K W and McCabe P J, SEPM Spec. Publ. 59 17-29.

Fielding C R 1986 Fluvial channel and over bank deposits from the Westphalian of the Durham coal field, NE England; Sedimentology 33 119-140.

Friend P F, Slater M J and Williams R C 1979 Vertical and lateral building of river sandstone bodies, Ebro Basin, Spain; Geol. Soc. London, Spec. Publ. 136 39-46.

Gibling M R 2006 Width and thickness of fluvial channel bodies and valley fills in the geological record: A literature compilation and classification; J. Sedim. Res. $\mathbf{7 6}$ 731-770.

He S, Yang Q and Qi J F 2008 Cenozoic fault systems and their genetic analysis in central area of the Huanghua depression; Scientia. Geol. Sinica. 43 533-545.

Huerta P, Armenteros I and Silva P G 2011 Large-scale architecture in non-marine basins: The response to the interplay between accommodation space and sediment supply; Sedimentology 58 1716-1736.

Hou J G, Liu M Y, Xu F and Zhang G Y 2008 Architecture of braided fluvial sand body and origin for petroliferous difference of the Guantao Formation of Neogene in Kongdian oil field of Huanghua depression; J. Palaeogeol. 10 459-464.

Jiao Y Q and Yan J X 2005 Architectural units and heterogeneity of channel reservoirs in the Karamay Formation, outcrop area of Karamay oil field, Junggar basin, northwest China; AAPG Bull. 89 529-545.

Jorgensen P J and Fielding C R 1996 Facies architecture of alluvial flood-basin deposits: Three-dimensional data from the Upper Triassic Callide Coal Measures of east-central Queensland, Australia; Sedimentology 43 479-495.

Li Y, Liao Q J and Xiao D Q 2014 Sequence stratigraphy of fluvial facies; China Science Publishing \& Media Ltd, Beijing, pp. 29-45.

Li M G, Qi J F and Yang Q 2009 Cenozoic structure features of Huanghua depression and its structure dynamics mode; Acta Geosci. Sinica. 30 201-209.

Li S Z, Suo Y H and Zhou L H 2011 Pull-apart basins within the north China craton: Structural pattern and evolution of Huanghua depression in Bohai Bay basin; J. Jilin University (Earth Sci. edn) 41 1363-1377.

Liao B F, Zhang W M and Li L 1998 Study on modern deposit of a braided stream and facies model-taking the Yongding river as an example; Acta Sedimentol. Sinica. 16 34-39.

Lu K Z 2001 Petroleum basin analysis; Petroleum Industry Press, Beijing, pp. 77-178.

Marenssi S A, Limarino C O, Tripaldi A and Net L I 2005 Fluvial systems variations in the Rio Leona Formation: Tectonic and eustatic controls on the Oligocene evolution of the Austral (Magallanes) Basin, southernmost Argentina; J. S. Amer. Earth Sci. 19 359-372. 
Miall A D 1977 A review of the braided-river depositional environment; Earth-Sci. Rev. 13 1-62.

Miall A D 1985 Architectural-element analysis: A new method of facies analysis applied to fluvial deposits; Earth-Sci. Rev. 22 261-308.

Miall A D 1993 The architecture of fluvial-deltaic sequences in the Upper Mesaverde Group (Upper Cretaceous), Book Cliffs, Utah; Geol. Soc. London, Spec. Publ. 75 305-332.

Nichols G J and Fisher J A 2007 Processes, facies and architecture of fluvial distributary system deposits; Sedim. Geol. 195 75-90.

Qi J F, Lu K Z, Zhang Y W and Yang Q 1994 The formation and evolution of Kongdian high in Huanghua Basin; Acta Petrol. Sinica. 15 27-33.

Qi P, Ren J Y and Lu G C 2010 Cenozoic episodic subsidence in the middle and north part of Huanghua depression, Bohai Bay Basin; Earth Sci. 35 27-33.

Smith G H S, Best J L, Ashworth P J, Fielding C R, Goodbred S L and Prokocki E W 2010 Fluvial form in modern continental sedimentary basins: Distributive fluvial systems: Comment; Geology 38230.

Straub K M, Paola C, Mohrig D, Wolinsky M A and George T 2009 Compensational stacking of channelized sedimentary deposits; J. Sedim. Res. 79 673-688.
Sun X X, Li Y, Qiu D Z, Xiao D Q, Wu Z G and Zhang L X 2006 The heavy minerals and provenances of the Neogene Guantao Formation in the Huanghua depression; Sedim. Geol. Tethyan Geol. 26 61-66.

Wu S H, Zhao X M, Yue D L, Wanyan Q Q, Zhang Y L and Liu L 2010 Sedimentary facies prediction of fluvial facies single channel using combined well-seismic data; Petrol. Geol. Oilfield Dev. Daqing 29 171-174.

Ye L, Zhang J X and Lu G C 2013 Paleogene structure stratigraphic framework and multiple episode evolution in Kongnan area, Huanghua depression; Earth Sci. 38379 389.

Yue D L 2006 The study on architecture analysis and remaining oil distribution patterns of meandering river reservoir; Chinese University of Petroleum, pp. 91-94.

Wang J S 2010 Comparison of depositional dynamics among the braided, meandering and straight channel reaches in the lower Yellow river; Acta Sedimentol. Sinica. $28307-$ 313.

Zeng H, Backus M M and Barrow K T 1998a Stratal slicing, Part I: Realistic 3-D seismic model; Geophysics 63 502513.

Zeng H, Stephen C H and Riola J P 1998b Stratal slicing, Part II: Real 3-D seismic data; Geophysics 63 514-522.

Corresponding editor: PARTha Pratim Chakraborty 